\title{
Clostridium paraputrificum
}

National Cancer Institute

\section{Source}

National Cancer Institute. Clostridium paraputrificum. NCI Thesaurus. Code C86287.

A species of anaerobic, Gram positive, rod shaped bacteria assigned to the phylum

Firmicutes. This species is endochitinase positive, mesophilic, hydrolyzes starch, reduces

nitrate and is indole positive. C. paraputrificum is pathogenic in humans but not in rabbits or guinea pigs. 